\title{
A argumentação de Arthur Ramos a favor da Psicanálise na Educação
}

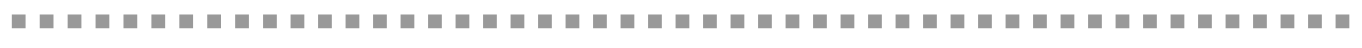 \\ Pesquisadora: Fabíola Sircilli \\ Instituição: Programa de Pós-Graduação (Mestrado) em Psicologia da Universida- \\ de de São Paulo (USP)/Faculdade de Filosofia, Ciências e Letras de \\ Ribeirão Preto. \\ Orientador: Prof. Dr. Marcus Vinicius da Cunha
}

Esta nota de pesquisa tem por objetivo apresentar alguns dados preliminares oriundos da análise do discurso educacional de Arthur Ramos, médico que trabalhou ao lado de Anísio Teixeira nos anos de 1930. Ramos, que tinha fortes ligações com a Psicanálise, dirigiu a Seção de Ortofrenia e Higiene Mental, quando Teixeira exercia a função de diretor da Instrução Pública do Distrito Federal, setor que passou a chamarse Departamento-Geral de Educação e, mais tarde, Secretaria de Educação. Ali Ramos oferecia atendimento às crianças nas chamadas Clínicas de Orientação Infantil, instaladas em escolas públicas da cidade. Empregou ali teorias psicanalíticas procurando transformá-las em meios aplicáveis à educação brasileira (Abrão, 2001, p. 118). Nossa investigação enfoca o livro Educação e psicanálise, de A. Ramos, publicado em 1934, realizando uma análise do encadeamento argumentativo do autor para verificar o modo como ele concilia as teorias psicanalíticas com outros conhecimentos, próprios da visão socializadora da educação renovada que vinculava os problemas educacionais à esfera da vida social, de acordo com o discurso predominante em sua época.

Adotamos para isso o referencial metodológico desenvolvido por Chaïm Perelman e Lucie Olbrechts-Tyteca (2002, p. 22), no qual considera-se que em todo discurso há um orador e um auditório, sendo este definido "como o conjunto daqueles que o orador quer influenciar com sua argumentação". Consideramos que qualquer autor, ao escrever e publicar um texto, tem a pretensão de atingir um determinado auditório, que são os seus eventuais leitores, esforçando-se, assim, para obter sua adesão a uma ou mais teses. Por esse motivo, os textos escritos são passíveis de ser analisados como peças argumentativas. Os pontos principais da análise retórica são as estratégias argumentativas presentes nos discursos, o condicionamento do auditório diante do discurso e a ordem na qual os argumentos devem ser apresentados para que sejam mais eficazes.

Perelman e Olbrechts-Tyteca propõem uma "nova retórica" em sua obra Tratado da argumentação, na qual retomam a dialética aristotélica, ou seja, a arte de raciocinar a partir de opiniões aceitas em geral, associada à teoria da argumentação. Não focalizam, no entanto, a argumentação oral ou dirigida à multidão reunida numa praça, como ocorria na antiga Grécia. Diferentemente da retórica clássica, os autores privilegiam os textos impressos, em busca de compreender os mecanismos do pensamento e da estrutura da argumentação, sem se importarem com o fato de determinada apresentação ser "pela palavra ou pela escrita, sem distinguir discurso em forma e expressão fragmentária do pensamento". O que se mantém, essencialmente, da retórica tradicional é a idéia de um auditório, automaticamente evocada assim que se pensa em um discurso (Perelman; Olbrechts-Tyteca, 2002, p. 5-7). Afinal, dizem os autores, o discurso oral é 
concebido tendo em vista um auditório, e o mesmo se pode dizer dos livros. Muito embora não haja a presença material de leitores, todo texto é elaborado de forma a sensibilizá-los, fazendo com que o conteúdo dialogue com aqueles que o lêem.

Em busca de uma metodologia de pesquisa que ofereça ferramentas para analisar "o modo como certos autores integram as idéias de outros às suas formulações", em especial no campo da educação, Cunha (2005, p. 181) traz uma série de reflexões sobre como os discursos pedagógicos são construídos. Nos termos de Cunha (2005, p. 195196), o discurso é o resultado de uma série de enunciados que visam transmitir idéias e teorias de um autor a seus leitores, indicando uma relação de mão dupla entre o orador e seu auditório. Em seu entender, a análise do discurso não deve levar em conta apenas o texto, mas também o contexto no qual um conceito ou idéia é apropriado por outrem para criar novas formulações. A Retórica de Aristóteles, que dá fundamento a esse tipo de análise, "remete a questões de ordem técnica, relativas à boa concatenação do raciocínio perante os ouvintes", o que evidencia, segundo Cunha, o valor de entendermos as disposições do auditório.

Assim sendo, a hipótese norteadora da pesquisa é que Ramos procurou, com seu livro, persuadir aqueles que eventualmente estivessem munidos de disposições contrárias às suas idéias, as quais seriam em breve aplicadas nos trabalhos da Seção de Ortofrenia e Higiene Mental, órgão público do Distrito Federal sob sua responsabilidade. Acreditamos que os argumentos de Ramos eram, na verdade, endereçados aos intelectuais da época, àqueles que tinham o poder administrativo e político em suas mãos e que, conseqüentemente, tinham forte influência na sociedade. É provável que Ramos pretendesse conquistar os membros da equipe de Anísio Teixeira, na qual estava ingressando, a fim de que aderissem às suas teses psicanalíticas, ou, pelo menos, que dessem aval para aplicá-las à educação. De outro lado, Ramos tinha a oposição clara dos pensadores e ativistas católicos da época, igualmente influentes na sociedade e, em particular, no campo educacional. Outro auditório a ser considerado é o dos higienistas, pois em setembro de 1933, recém-chegado ao Rio de Janeiro, Ramos filiou-se à Liga Brasileira de Higiene Mental (LBHM), onde, em seguida, realizou uma conferência intitulada "A psicanálise infantil e sua importância na higiene mental e na Pedagogia" (Silva, 1998, p. 119).

Nosso objetivo é precisamente compreender as estratégias adotadas por Ramos, tomando, para isso, a articulação do discurso do autor em todo o livro, razão pela qual iremos analisar Psicanálise e educação como um livro-argumento no qual consideramos que a intenção de Ramos era a de apresentar as teses psicanalíticas como ferramentas educacionais agregadoras de benefícios para a escola.

\section{Referências bibliográficas}

ABRÃO, J. L. F. A história da Psicanálise de crianças no Brasil. São Paulo: Escuta, 2001.

CUNHA, M. V. Recontextualização e Retórica na análise de Discursos Pedagógicos. In: SOUZA, R. F.; VALDEMARIM, V. T. (Org.). A cultura escolar em debate: questões conceituais, metodológicas e desafios para a pesquisa. Campinas: Autores Associados, 2005.

PERELMAN, C.; OLBRECHTES-TYTECA, L. Tratado da argumentação: a nova retórica. Trad. Maria Ermantina Galvão. São Paulo: Martins Fontes, 2002.

RAMOS, A. Educação e Psicanálise. São Paulo: Cia. Editora Nacional, 1934.

SILVA, A. S. R. Cuidando do futuro do Brasil: infância, educação e higiene mental na obra de Arthur Ramos. Dissertação (Mestrado) - Universidade Federal do Rio de Janeiro, Instituto de Psiquiatria, Rio de Janeiro, 1998. 